\title{
Holocene evolution of the coast of Holland
}

\author{
D.J. Beets ${ }^{\mathrm{a}}$, L. van der Valk ${ }^{\mathrm{b}}$ and M.J.F. Stive \\ ${ }^{\mathrm{a}}$ Geological Survey of the Netherlands, P.O. Box 157,2000 AD Haarlem, The Netherlands \\ ${ }^{\mathrm{b}}$ Free University of Amsterdam, Institute of Earth Sciences, De Boelelaan 1085, $1081 \mathrm{MV}$ Amsterdam. The Netherlands \\ ${ }^{'}$ Delft Hydraulics, P.O. Box 152,8300 AD Emmeloord, The Netherlands
}

(Received January 9, 1991; revision accepted March 25, 1991)

\begin{abstract}
Beets, D.J., Van der Valk, L. and Stive, M.J.F., 1992. Holocene evolution of the coast of Holland. Mar, Geol, 103: 423-443.

The Holocene evolution of the coast of Holland was controlled by the complex interaction of such diverse parameters as wave and tidal climate, the rate of sea-level rise, and the morphology of the pre-transgressional surface. The latter, in combination with the rate of sea-level rise, mainly determines the location of sediment sources and sinks, while the hydrodynamic parameters mainly determine the rate and direction of sediment transport. In the early Holocene the low sea level in the shallow southern North Sea strongly affected wave climate and tidal regimc. However, the barrier and back-barrier sedimentary record since $5000{ }^{14} \mathrm{C}$ yrs B.P. gives us no reason to assume major changes in these parameters since then, so we conclude that breaks in barrier development are due to variations in rate of sea-level rise in combination with the morphology of the pre-transgressional surface.

The transformation from an open "tide-dominated" to a closed "wave-dominated" coast, which occurred in the Subboreal period, and the concomitant change in barrier movement from transgressive to regressive around 5000 yrs B.P. are the main events in the development of the coast of Holland up to the Middle Ages. The morphology of the pre-transgressional surface gives a shoreline in the late Atlantic which consists of two protruding headlands separated by a large tidal basin.

The southern headland is the alluvial plain of the Rhine and the Meuse, the northern headland constitutes the moraines of the Texel High. The tidal basin in between is connected to the North Sea by a large number of inlets. The rate of sea-level rise at that time ( $1 \mathrm{~m} /$ century) outran the supply of sediment to the tidal basin. After 6000 yrs B.P. the rate of sea-level rise decreased gradually, whereas the rate of sediment supply remained constant. This led to a gradual decrease in the tidal prisms of the inlets as the tidal basin was filled in with sediment. Shortly before 5000 yrs B.P. the first channels silted up and closed; the last tidal channel disappeared around $3300 \mathrm{yrs}$ B.P., leaving two inlets along the coast which were both connected to the river Rhine. The closure of the first inlets occurred at the same time as the barrier began prograding because (1) the rate of sea-level rise diminished considerably, (2) not all the sand supplied by longshore and cross-shore transport disappeared into the tidal basin, but instead could be used for barrier progradation; and (3) ebb-tidal deltas of the closed inlets provided major sand sources.

The prograding barrier sequence enclosed between the two headlands roughly forms a closed system. Using the relationships between tidal prism, cross-sectional area of inlets and volume of the ebb-tidal delta, and the results of modelling of longshore transport along the Subboreal const under present-day wave conditions, a simple sand budget for the coast of Holland is given which shows that a large part of the sand now stored in the barricr sequence was obtained by cross-shore transport from the North Sea.
\end{abstract}

\section{Introduction}

In 1985 a project on the large-scale and longterm behaviour of the Dutch coast called "Coastal Genesis", was started in order to obtain a better insight into the factors and conditions causing coastal change. The main aim of the project is to construct conceptual and physical-mathematical models of the hydrodynamic and morphodynamic processes so that coastal behaviour can be predicted for the coming 10 to 100 years. The Coastal Genesis Project is a cooperative effort between coastal engineers, physical geographers, historians and geologists from universities and research institutes that is financed by the ministries of Transport and Public Works, Economic Affairs, and Science and Education.

The basic data for the project are yearly meas- 
urements since about 1850 on the position of the dune foot and the mean high and low waterline relative to a fixed reference line, and yearly measurements since 1963 of the coastal profile along about 3000 fixed lines perpendicular to the coast up to $800 \mathrm{~m}$ offshore. (Once every 5 years some of these soundings are extended to $2500 \mathrm{~m}$ offshore.) In addition, the beach and dunes are monitored by aerial surveys, and inlets and other important waterways are regularly monitored by soundings. Although these data give a good picture of the behaviour of the coastline since 1850 and the coastal profile since 1963 , we felt it necessary to extend these records with historical and geological data where possible. Although less accurate, these much longer records better reflect the main trends in coastal evolution, and as such are impor- tant in the formulation of conceptual models to be used for prediction. In this paper the relationship between the short-term (since 1850) and longterm (since $5000{ }^{14} \mathrm{C}$ yrs B.P.) behaviour of the coast of Holland between Rotterdam in the south and the Frisian Islands in the north is reviewed. Note that all ages, unless otherwise indicated, are given in conventional ${ }^{14} \mathrm{C}$ years.

\section{The shoreline of The Netherlands}

The shoreline of The Netherlands forms part of a barrier system along the southeastern shore of the North Sea from the northern tip of France up to and including Denmark (Fig.1). The trend of barriers in The Netherlands varies from almost $\mathrm{N}-\mathrm{S}$ in the west to almost $\mathrm{E}-\mathrm{W}$ in the north. The

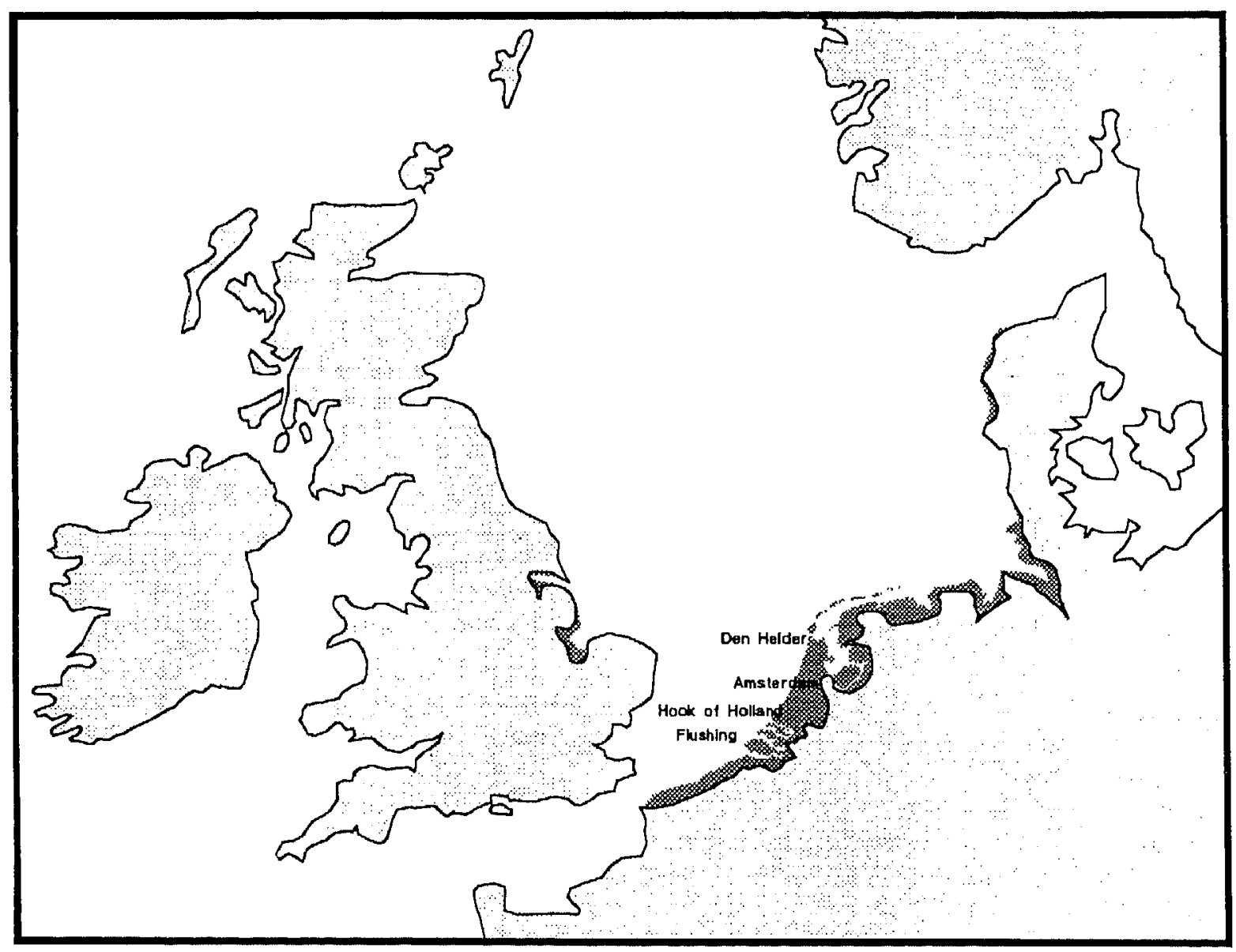

Fig.1. Maximum extent of the Holocene transgression in the North Sea area. 
shape of the coastline was inherited from the older Pleistocene morphology, but was strongly modified by Holocene coastal processes.

In the classification of Davis and Hayes (1984) the Dutch coast is a mixed energy coast, with both tides and waves shaping its morphology. The tidal climate is predominantly defined by the tidal wave coming in from the north and rotating anticlockwise around two amphidromic points, one between The Netherlands and the east coast of Norfolk (UK) and the other north of The Netherlands and west of Denmark. South of Rotterdam the tides are also influenced by the tidal wave from the English Channel. This results in a strongly varying mean tidal range along the coast, from $4 \mathrm{~m}$ in the south to less than $2 \mathrm{~m}$ along the coastal stretch between Rotterdam and the Frisian Islands. Along the Frisian Islands the mean tidal range gradually increases eastwards from $1.35 \mathrm{~m}$ near Texel to $2.10 \mathrm{~m}$ near the border with Germany (Fig.2).

Analyses of wind directions along the coast in the period between 1700 and 1940 shows that the southwest is the most common direction (23\%), followed by west $(16 \%)$, east (13\%) and northwest

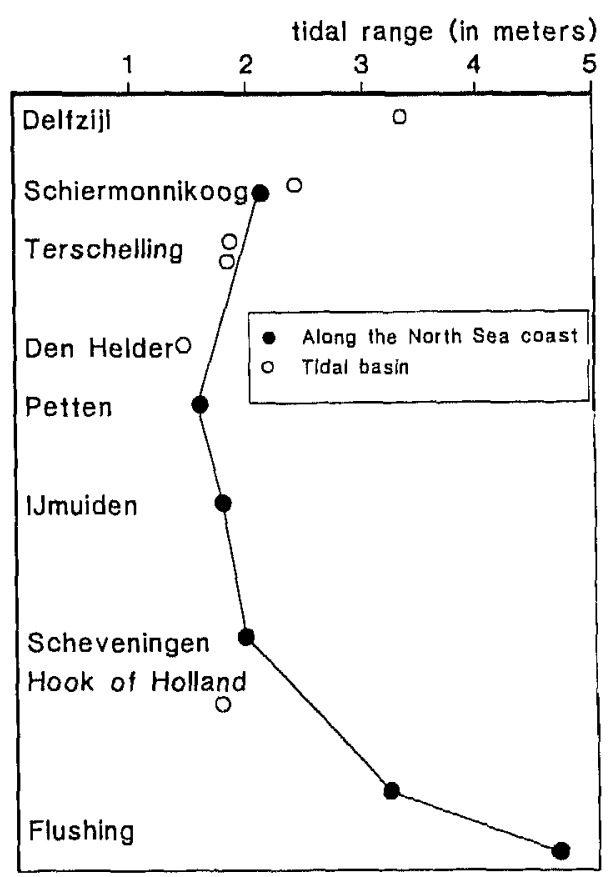

Fig.2. Variation in tidal range along the Dutch coast (after Stolk, 1989).
(12\%) (Kollen, 1987; Stolk, 1989). The dominant wind speeds of over $15 \mathrm{~m} / \mathrm{s}$ ( 7 on the Beaufort scale) are mainly from the west and northwest (Sha, 1989). As shown by Van Straaten (1961) there is a close correlation between wind and wave climate. The mean significant wave height is $1.1 \mathrm{~m}$ in the south (Kohsiek, 1988) and $1.8 \mathrm{~m}$ in the north (Sha, 1989).

On the basis of its morphology, the present coast of The Netherlands may be subdivided into three coastal subsystems which basically differ with respect to the dominance of particular physical processes.

In the south of The Netherlands the Zeeland area consists of peninsulas separated by estuaries and inlets. The present morphology was established in post-Roman times by successive and often catastrophic flooding (Van den Berg, 1986). Inundation of large parts of the Zeeland area is considered to be related to peat exploitation and agricultural activity in the Middle Ages. The present flood defence works in the region were prompted by the flood disaster in February 1953. They mainly consist of permanent closure works for the estuary arms, and have changed the delta into more or less a relic. One of the arms, the Westerscheldt estuary mouth, is a very active system of bars and channels which has an important impact on the form of coastline undulations along the adjacent coastal stretches.

In the north of The Netherlands the Frisian Islands form a chain of barrier islands separated from the mainland by the Wadden Sea, a tidal basin with extensive tidal flats. The barrier islands are relatively long and the tidal inlet channels between them are characterized by active delta systems. The present form of the Wadden Sea was essentially attained a thousand years ago, when important breaches occurred towards the former Almere lagoon in the centre of Holland, thus creating the Zuiderzee. A characteristic feature of the Wadden Sea region is continuous sedimentation on its tidal flats in order to keep pace with relative sea-level rise, and silting along the Wadden shores. These processes are responsible for an important influx of sand, which is essentially delivered by the adjacent coastal system.

The central part of the coast of The Netherlands 
is the Holland coast, and the origin and Holocene evolution of this area is the main subject of this paper.

\section{The coast of Holland}

\section{General description}

This area comprises an uninterrupted, slighly curved stretch of coast running SSW-NNE over a distance of almost $120 \mathrm{~km}$ from the entrance of Rotterdam Harbour near the Hook of Holland in the south to the port of Den Helder in the north. About midway is the man-made entrance of Amsterdam Harbour near IJmuiden. North of the village of Bergen the barrier is interrupted by the former Zijpe inlet, which was closed in about 1550 by dykes; this is now the Hondsbosse Sea Defence (Fig.3).

North of this dyke the barrier is narrow and consists of a beach and a few dune ridges. The barrier reached its present position in the 16th century (Schoorl, 1973). South of the Hondsbosse Sea Defence, the barrier is a $\leqslant 10 \mathrm{~km}$ wide complex of partly overblown ridges and beach plains formed by progradation after about $5000{ }^{14} \mathrm{C}$ yrs B.P. (Van Straaten, 1965; Jelgersma et al., 1970). South of Scheveningen this barrier complex curves westward and is truncated by the present shoreline.

The coast of Holland has a wave-dominated morphology with a steep, concave and barred shoreface. The toe of the shoreface lies at a depth of about $20 \mathrm{~m}$ along the northern and southern part of the coast and at about $15 \mathrm{~m}$ in the central part. The slope of the shoreface varies from about $1: 400$ in the north and the south to $1: 165$ in the central part (Van Alphen and Damoiseaux, 1989). Bars occur to a depth of $8 \mathrm{~m}$ below sea level along the entire coast, except for the area south of Scheveningen. The number of bars varies from two to five, including the intertidal bar.

The beach is generally $100-200 \mathrm{~m}$ wide, measured between the low water line and the dune foot. The slope of the beach between the high and low water line varies between 1:35 and 1:60. The morphology of the beach is dependent on the wave conditions. Quiet conditions promote the construction of a berm, and an intertidal bar separated from the berm by a runnel. Storm waves will flatten the beach and destroy the berm and bar (Reineck and Singh, 1973; Van den Berg, 1977).

Coastal dunes flank the beach over the entire length of the coast. The dune complex varies in width from a few hundred metres to more than $5 \mathrm{~km}$. Dunes may become as high as $50 \mathrm{~m}$, but those flanking the beach generally have a maximum height of $20-30 \mathrm{~m}$. The mean grain size in the shoreface, beach and flanking dunes is $125-250$ $\mu \mathrm{m}, 250-300 \mu \mathrm{m}$, and $200-250 \mu \mathrm{m}$ respectively (Eisma, 1968; Stolk, 1989).

At present, the coast of Holland is retreating between the Hook of Holland and Scheveningen in the south, and between Bergen and Den Helder in the north. In the central part the shoreline is prograding slightly (Fig.4). The rate of retreat is about $0.35 \mathrm{~m} / \mathrm{yr}$ in the south and $0.70-0.95 \mathrm{~m} / \mathrm{yr}$ in the north. These rates are statistical means based on the yearly measurements of the position of the dune foot and high and low water line since 1850 (Van Vessem, 1989). Initially, this pattern of erosion and progradation was explained by Edelman and Eggink (1962) as being predominantly due to gradients in longshore transport caused by the curvature of the shoreline. However, on the basis of heavy mineral analyses of coastal sands, Eisma (1968) stressed the importance of cross-shore transport on the coast of Holland. At present, this latter view is quantitatively supported in the sense that cross-shore transport, not only within the breaker zone but including the exchange of sand between the shelf and the shoreface, is responsible for most of the progradation along the central part of the coast of Holland (Wiersma and Van Alphen, 1988; Stive, 1987, 1989). Erosion in the north is thought to be largely due to loss of sand to the Wadden Sea by way of Texel Inlet (Stive, 1989) in response to a relative sea-level rise of $0.15-0.20 \mathrm{~m}$ in the past 100 years (De Ronde, 1982; Van Malde, 1984). The present erosion in the south is ascribed by Dijkman et al. (1990) and Stive et al. (1990) to net northward longshore losses due to wave and tidal motion enhanced by the harbour moles and entrance channels of the ports of Rotterdam and Scheveningen.

As has already been concluded by Van Straaten (1965), long-term geological development indicates 


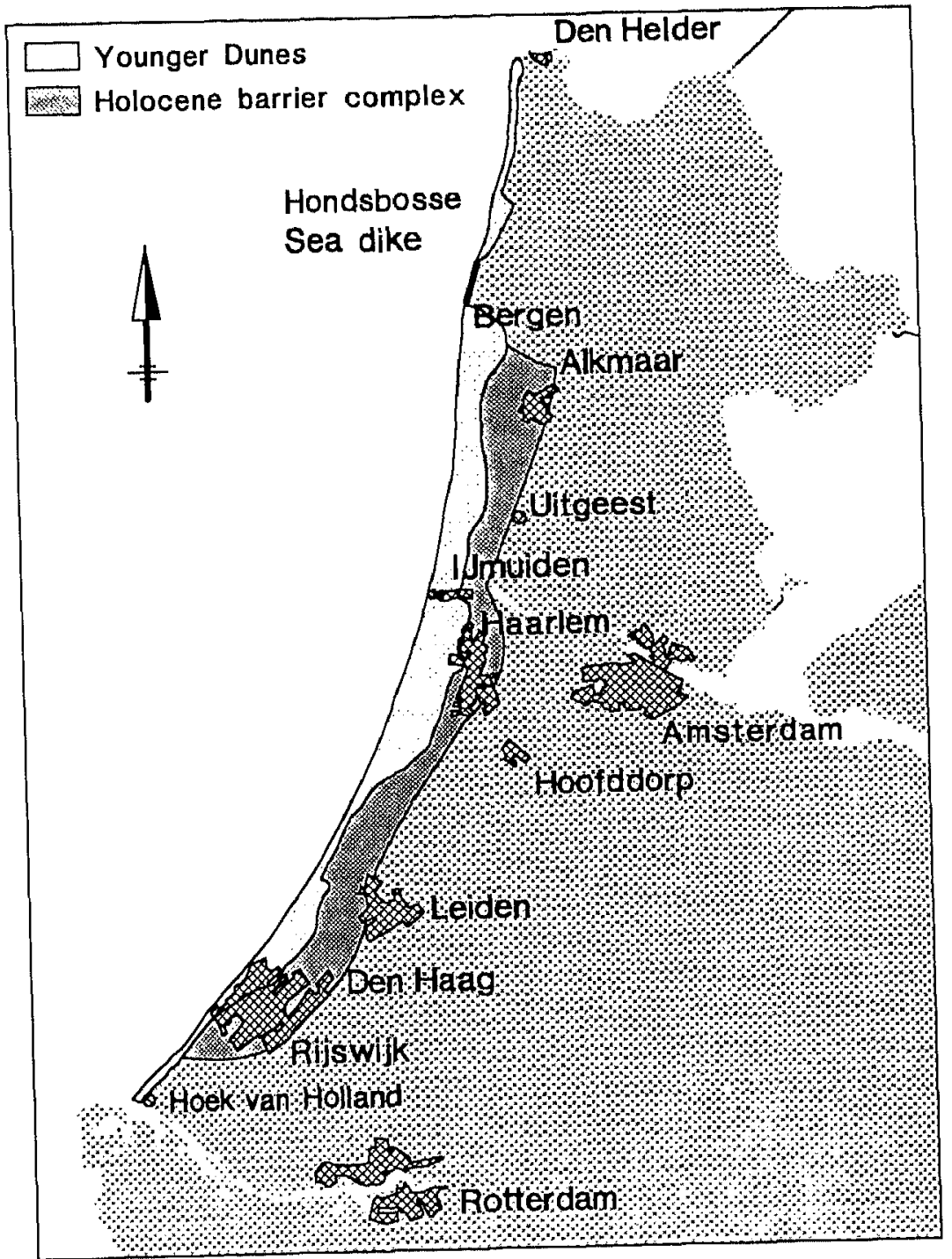

Fig 3. The Holocene barrier complex along the coast of Holland. The Younger Dunes are the medieval and younger coastal dunes covering the older barrier complex.

that both cross-shore and long-shore processes have played an important role in the evolution of the coast of Holland. Although (as will be discussed below) their relative magnitudes and response scales have shown some variation through geological time, the long-term orders of magnitude of these processes are approximately equal. At present, however, it appears that due to human interference and regulation measures segmentation of a large part of the Holland coast is being created, which suppresses net long-shore losses.

The long-term development also shows that the present pattern of erosion and progradation of the coast of Holland has a long history, and chiefly arises from morphological differences in the pretransgressional surface.

The Pleistocene surface of the western Netherlands

A simplified picture of the top of the late Weichselian surface beneath Dutch Ordnance Level ( $\simeq$ Mean Sea-Level) is given in Fig.5. The surface has a distinct $\mathrm{E}-\mathrm{W}$ structure and consists of two wide, shallow valleys separated by low 


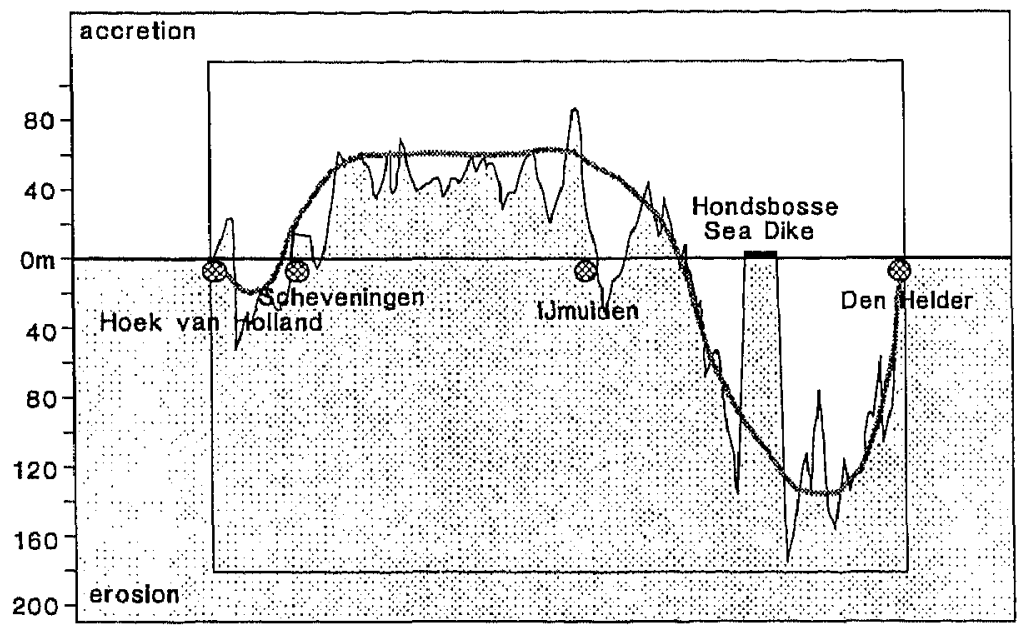

Fig.4. Hundred year mean coastline changes along the Holland coast (simplified after Edelman and Eggink, 1962).

divides. The southern valley, which has its deepest part in the Rotterdam-Hook of Holland area, is the Late Glacial course of the rivers Rhine and Meuse. During most of the Holocene the rivers continued to follow this course. Only during the Subboreal and Early Subatlantic did the main tributary of the Rhine shift its position temporarily, after which it returned to its original course after Roman times (Zagwijn, 1986; Pruissers and De Gans, 1988). A $40-50 \mathrm{~km}$ wide, flat divide separates the Rhine/Meuse valley from the northern valley, which is the confluence of a number of small streams draining the area which surrounds the northern valley. The present remnants of these streams are the Overijsselse Vecht in the eastern part of The Netherlands, and the Eem in the central part. The Texel High, an E-W ridge of Saalian pushed moraines (Jelgersma, 1961; Pons et al., 1963; Ter Wee, 1983) is the northern divide of this valley.

The outcropping Pleistocene sediments consist predominantly of aeolian cover sands and coarse sandy river deposits of Weichselian age. Consequently, the Pleistocene surface provides sufficient sand for barrier construction. Although the westerly extent of the Texel High is uncertain because of destruction by the landward migration of the barrier, it seems likely that this ridge, because of its protruding nature, was a major source of sand during the Holocene barrier evolution. As the Rhine and Meuse followed their original course throughout most of the Holocene, and fill up their alluvial plain in response to the rapid sea-level rise, this area becomes another source of sand to feed the barrier. The discharge of the local streams of the northern valley decreases strongly at the start of the Holocene, and, unlike that of the Rhine/Meuse, this valley changes into a tidal basin which becomes a major sink of sand and mud (Pons et al., 1963; Pons and Wiggers, 1959-1960). Consequently, the main trend throughout the Holocene is erosion of the Texel High and the Rhine/Meuse estuary and deposition in the area between-in broad terms the pattern of progradation and erosion of today. Eventually, this pattern of progradation and erosion erased the E-W structure of the late Weichselian surface and replaced it by a smooth SSW-NNE coastline, which, at first sight, has little in common with the original morphology.

\section{Holocene relative sea-level rise}

On a time scale of several thousands of years, relative sea-level rise is one of the most important factors controlling barrier evolution. The sea-level curve for the western Netherlands is shown in Fig.6. It is largely based on the data of Jelgersma (1961) and Van de Plassche (1982). More recent data (Roep and Beets, 1988; Van de Plassche and Roep, 1989) improve its accuracy in the range $5000-2000{ }^{14} \mathrm{C}$ yrs B.P., but do not add elements 


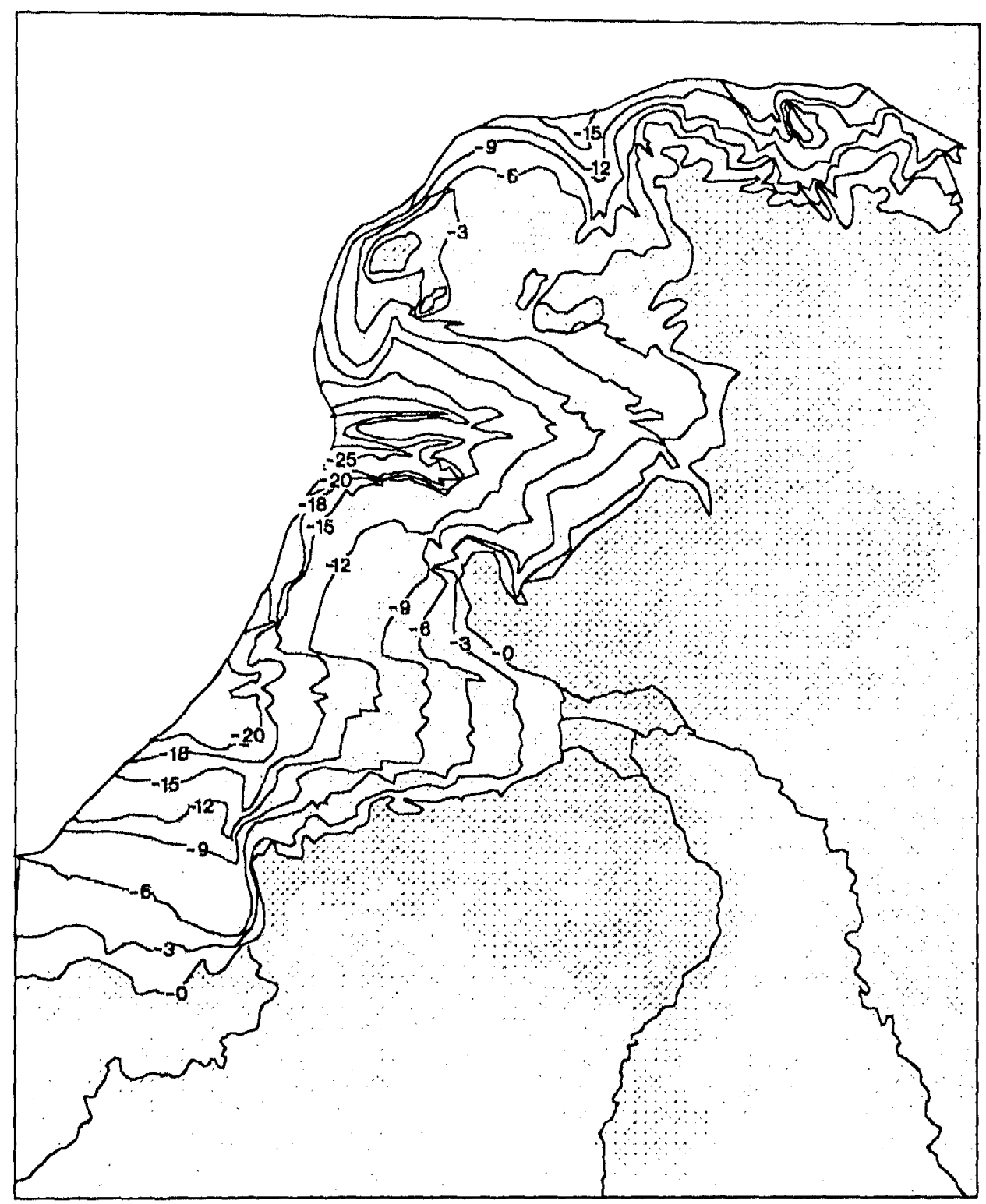

Fig.5. Morphology of the Late Glacial surface (after Zagwijn, 1986). Contours in metres.

which are essential to this paper. The curve shows a rapid sea-level rise ( $>1 \mathrm{~m} / \mathrm{century}$ ) until about $6000{ }^{14} \mathrm{C}$ yrs B.P., after which the rate gradually decreased to $0.05 \mathrm{~m} /$ century during the past 2000 years. As mentioned earlier, a rate of sea-level rise of $0.15-0.20 \mathrm{~m} /$ century has been measured since systematic monitoring started around 1850 .

Note that at the start of the Subboreal, when progradation of the barrier complex of the coast of Holland started, mean sea-level was still $5 \mathrm{~m}$ below the present level.

Paleogeography of the shoreline shortly before progradation

Stabilization of the transgressive barrier system started shortly before 5000 yrs B.P. east of Haarlem and east of The Hague (Fig.7). South of 


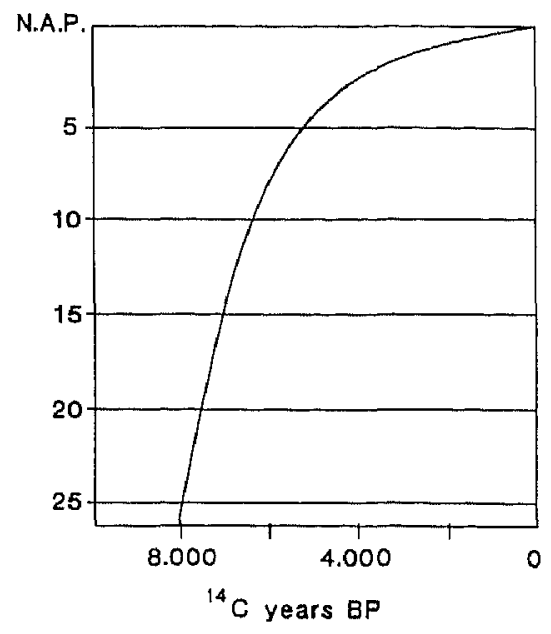

Fig.6. Curve for the Holocene sea-level rise around the western Netherlands (after Jelgersma, 1961 and Van de Plassche, 1982). N.A.P. $=$ Nieuwe Amsterdamse Peil (sea level).

Haarlem the barrier was offset by a tidal inlet, which, in the next 1000 years, developed into the main mouth of the River Rhine (Pons et al., 1963; Zagwijn, 1986; Pruissers and De Gans, 1988). Southeast of The Hague the barrier bent westward and at present is truncated by the shoreline $10 \mathrm{~km}$ north of Hook of Holland. The exact position of the coastline north of Haarlem is unknown, as it was still shifting eastwards at that time. The oldest preserved linear barrier in this area dates from about 4500 yrs B.P. (Westerhoff et al., 1987). At 5000 yrs B.P. the coast north of Haarlem was made up of a number of barrier islands separated by major E-W channels. Slightly before this time more channels cut the coast when there were tidal inlets at Rijswijk (Van der Valk et al., 1985) and south of Haarlem (Haans, 1954), so the coast of Holland was "open" at around $5500 \mathrm{yrs}{ }^{14} \mathrm{C}$ B.P. (Beets et al., 1985). As will be described below, between 5500 and 1500 yrs B.P. the channels successively silted up and at the same time their inlets closed. Due to these events an important mechanism was created for the progradation of the barrier system. This mechanism was very similar to that observed recently after the closure of the Grevelingen estuary in the Zeeland region (Kohsiek, 1988). The basic process involves crossshore sand transport induced by wave asymmetry (Stive, 1986), and the major sand source contained in the ebb-tidal deltas is used for the barrier progradation. An additional argument in support of this process is the hindcast of the wave climate in the period up to $5000 \mathrm{yrs}$ B.P. as made in Stive (1987). As Fig.8 shows, strong increase is expected to have taken place in the values of various wave characteristics, and especially in the wave skewness, which is an important, near-linear measure of sand transport induced by wave asymmetry.

The large number of inlets on the coast of Holland between 6000 and 5000 yrs B.P. occurred as a consequence of the size of the tidal basin, and was not due to a larger tidal range as was initially thought (Beets et al., 1985). The tidal range along the coast was $10-25 \%$ less than at present, as may be seen from modelling of the tidal conditions in the North Sea at lower sea-level stands (Franken, 1987). The large size of the tidal basin was primarily due to the morphology of the Pleistocene surface. In addition, the rate of sediment supply prior to 6000 yrs B.P. was insufficient to compensate for the fast sea-level rise, so around $5000 \mathrm{yrs}$ B.P. the valley of the Overijsselse Vecht was still recognizable in the shape of the tidal basin (Fig.7).

Table 2 gives an estimate of the collective crosssectional area of the inlets on the coast of Holland between 6000 and 5000 yrs B.P. using the relationship between cross-sectional area of tidal inlets and their mean tidal prisms (O'Brien, 1969; Van den Berg, 1986). The mean tidal prism depends on the size of the tidal basin at mean high water and the tidal range at the inlet. However, because of the presence of intertidal flats, which reduce the volume of the basin and dissipate the tidal wave energy, the product of size of the tidal basin and tidal range at the inlet places an upper boundary on the mean tidal prism. Because the paleomorphology of the basins is insufficiently understood, we have tried to correct the overestimation by an indirect approach. In Fig.9 we have plotted the measured mean tidal prisms of the inlets of the Dutch part of the Wadden Sea versus their theoretical tidal prism obtained by multiplying the tidal range at the inlet and the size of the tidal basins (for data, see Table 1). This plot shows that the tidal prism of most of the recent inlets is roughly $80 \%$ of that calculated from tidal range and size 


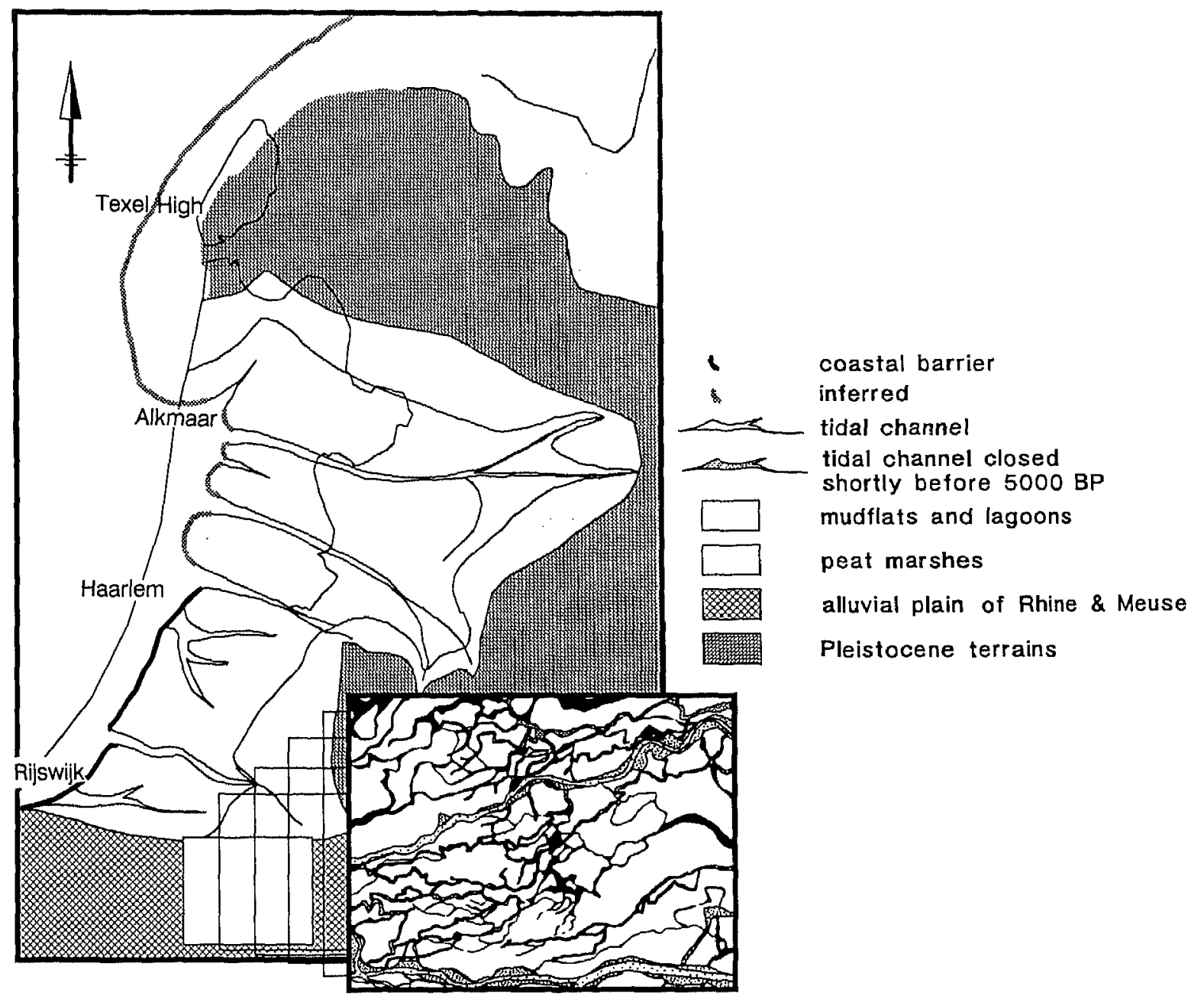

Fig.7. Paleogeography of Texel High, the tidal basin of Holland, and the oldest preserved barriers around 5000 yrs B.P. Inset is also shown in Fig.11.

of basin. We have used this factor to estimate the mean tidal prisms of closed inlets. Accordingly, the cross-sectional area of the combined inlets north of the line Haarlem-Amsterdam is estimated to have been $190,000 \mathrm{~m}^{2}$, whereas that of the combined inlets south of this line is $90,000 \mathrm{~m}^{2}$ (Table 2). The Texel Inlet and the Vlie, two of the major inlets of the present Wadden Sea, have cross-sectional areas of 70,000 and $60,000 \mathrm{~m}^{2}$ respectively.

Of course, these are very rough estimates, but the order of magnitude of the outcome of the calculations strengthens the geological data and confirms that major channel systems developed to feed the large tidal basin formed from the former valley of the Overijsselse Vecht. As mentioned earlier, the channels subsequently silted up, so that sand from the ebb-tidal deltas became available for the progradation of the barrier system. In Table 2 an estimate of the amount of sand stored in the ebb-tidal deltas of the former inlets of the Holland coast is given using the relationship between tidal prism and volume of ebb-tidal delta as developed by Bruun (1978).

Closure of the channels occurred because of a decrease in tidal volume, which was basically due to slackening of the sea-level rise (Fig.6). The channel near Rijswijk (Van der Valk et al., 1985) 


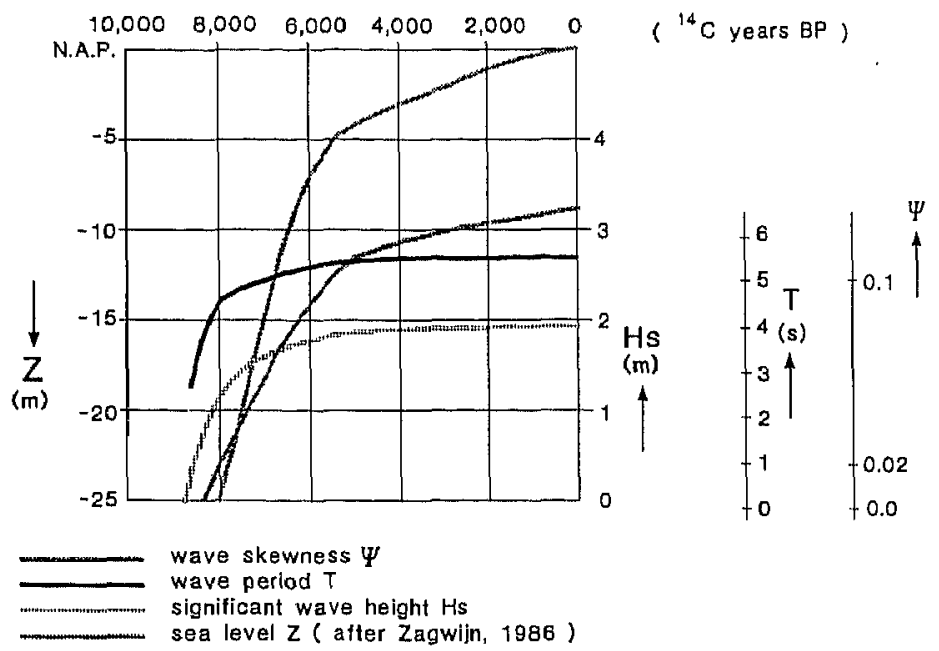

Fig.8. Estimated variation in wave characteristics in the Holocene on the central Holland coast (after Stive, 1987).

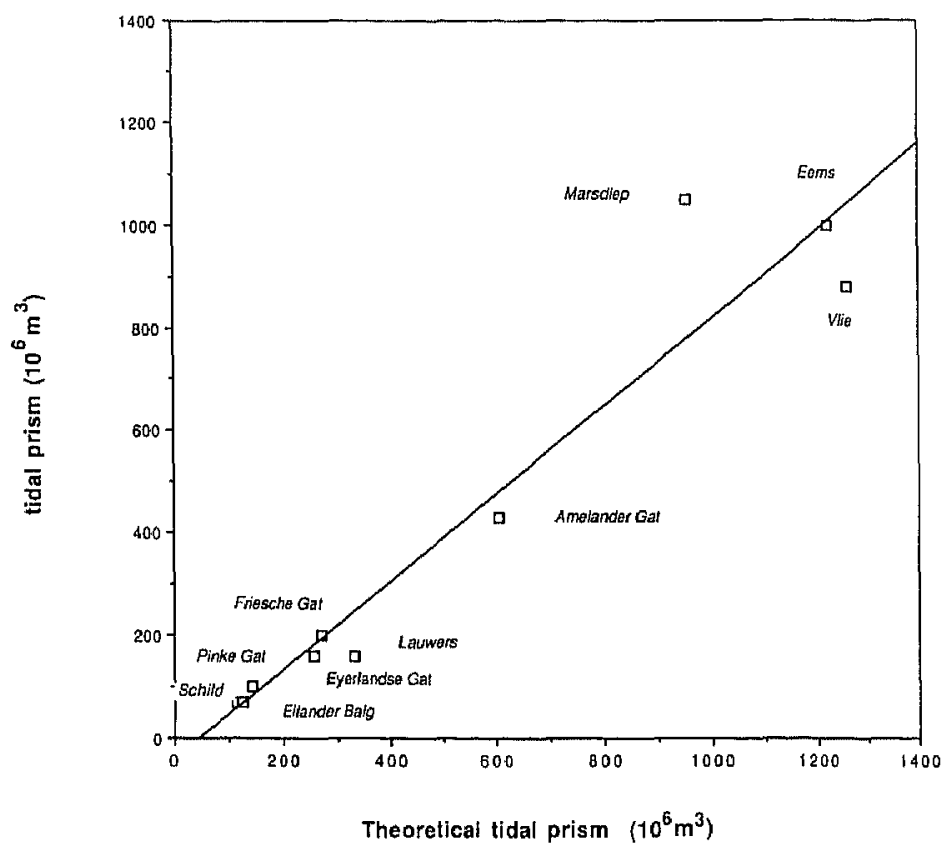

Fig.9. Relationship between measured tidal prism and theoretical tidal prism of the Dutch Wadden Sea inlets. Theoretical tidal prism is calculated by multiplying the size of the tidal basin at mean high water $\left(\mathrm{m}^{2}\right)$ by the tidal range in the inlet $(\mathrm{m})$.

and the one south of Haarlem, the Hoofddorp channel system, closed between 5500 and $5000 \mathrm{yr}$ B.P. Between 5000 and 4500 yrs B.P. this was followed by the silting up of the large Uitgeest channel (Fig.7) and a smaller one to the north of it (Westerhoff et al., 1987). At 4000 yrs B.P. only three channels remained: (1) the one near Leiden, which by then had developed into the main discharge channel of the Rhine (2) the Oer-IJ, which developed into another, much smaller branch of the Rhine, and (3) the Alkmaar-Bergen Inlet. The latter closed between 3500 and 3000 yrs B.P., but until that time was the major sink for sand along the coast. Finally, the Oer-IJ Inlet closed around 
TABLE ।

Data for the tidal inlets of the Dutch Wadden Sea

\begin{tabular}{lrlrrr}
\hline & \multicolumn{1}{l}{ I } & 2 & 3 & \multicolumn{1}{l}{4} & \multicolumn{1}{l}{5} \\
\hline Marsdiep & 680 & 1.40 & 952 & 1050 & 820 \\
Eijerlandse Gat & 160 & 1.60 & 256 & 160 & 81 \\
Vlie & 720 & 1.75 & 1260 & 880 & 660 \\
Amelander Gat & 310 & 1.95 & 605 & 430 & 273 \\
Pinke Gat & 65 & 2.15 & 140 & 100 & 45 \\
Friesche Gat & 130 & 2.15 & 280 & 200 & 107 \\
Eilander Balg & 55 & 2.25 & 124 & 70 & 29 \\
Lauwers & 145 & 2.30 & 334 & 160 & 81 \\
Schild & 50 & 2.35 & 118 & 70 & 29 \\
Eems & 520 & 2.35 & 1222 & 1000 & 772 \\
\hline
\end{tabular}

$1=$ Size of the tidal basin at mean high water in square kilometres.

$2=$ Mean tidal range in inlet in metres.

$3=$ Theorctical mean tidal prism: $V_{1}$ (size of the tidal basin $\times$ mean tidal range) in cubic metres $\times 10^{6}$.

$4=$ Mean tidal prism in cubic metres $\times 10^{6}: V_{m}$ (mean tidal prism of inlet).

$5=$ Calculated volume in cubic metres $\times 10^{6}$ of ebb-tidal deltas: $V_{b d}=6.57 \times 10^{-3} \times V_{\mathrm{m}}^{1.23}$. $V_{\mathrm{hd}}=$ volume of ebb-tidal delta (after Bruun, 1978 and Eysink, 1990).

$2000 \mathrm{yrs}$ B.P. and Leiden Inlet around $1200 \mathrm{AD}$ (Zagwijn, 1986; Pruissers and De Gans, 1988; Roep, 1984; Westerhoff et al., 1987).

At 5000 yrs B.P. this developing barrier sequence was enclosed between the Texel High north of Bergen and the cuspate delta plain of the rivers Rhine and Meuse south of Scheveningen. Both sandy, soft-rock promontories have been worn away, so their history can only be reconstructed indirectly.

At 5000 yrs B.P., with the sea level $5 \mathrm{~m}$ below present, the Texel High still comprised an E-W ridge that separated the tidal basin of Holland from that of the predecessor of the Wadden Sea (Fig.7). Its offshore extent is unknown, but, based on historical documents and maps, Schoorl (1973) reconstructed the medieval shoreline at varying distances (on the order of kilometres) offshore of Den Helder, which suggests that at the much lower sea level of 5000 yrs B.P. the coastline was situated still further westwards. The E-W trend of the hooked spit of Bergen (Fig.10), which formed the southern boundary of the Texel High and the west bank of the Alkmaar-Bergen Inlet, seems to confirm this.

The strike of the barrier southwest of Rijswijk (Figs.7 and 10) shows that the alluvial plain of the Rhine and Meuse extended offshore at 5000 yrs B.P. At present, the rivers carry virtually no sand to the shoreline. Whether they brought sand to the seashore at 5000 yrs B.P. is not known. Considering the high rate of sea-level rise during the Atlantic it is not very likely; most sand was probably deposited on the alluvial plain to compensate for the sea-level rise. The Holocene deposits of the alluvial plain east of Rotterdam (Fig.11) show a large number of sandy channel fills "floating" in swamp peats and clay-rich overbank deposits. Channel deposits in this area vary in age from early Holocene to recent, but the intricate network of small channel fills of Fig. 11 dates mainly from the late Atlantic (6000-5000 yrs B.P.; Hageman, 1969; Van de Meene, 1984). Comparable alluvial deposits, but of greater age, must have existed in the present offshore area when sea level was lower.

TABLE 2

Calculated combined tidal prisms, cross sections, and volume of ebb-tidal deltas of tidai inlets of the Holland coast prior to 5000 yrs B.P. (See Fig.7)

\begin{tabular}{lllllll}
\hline & 1 & 2 & 3 & 4 & 5 & 6 \\
\hline north of the line Amsterdam-Haarlem & 2400 & 1.4 & 3360 & 2700 & 190000 & $2.5 \times 10^{9}$ \\
south of the line Amsterdam-Haarlem & 1200 & 1.4 & 1680 & 1300 & 90000 & $1.0 \times 10^{9}$ \\
\hline
\end{tabular}

$1=$ Size of the tidal basin in square kilometres.

$2=$ Tidal range in metres.

$3=$ Theoretical tidal prism: $V_{t}$ (surface tidal basin $\times$ tidal range) in cubic metres.

$4=$ Calculated tidal prism: $V_{\mathrm{c}} \approx 0.8 V_{1}$ in cubic metres (Fig.9).

$5=$ Combined inlet cross section $F=70 V_{\mathrm{c}} \cdot 10^{-6}$ in square metres.

$6=$ Volume of ebb-tidal delta in cubic metres: $V_{b d}=6.57 \times 10^{-3} \times{V_{c}}^{1.23}$. 


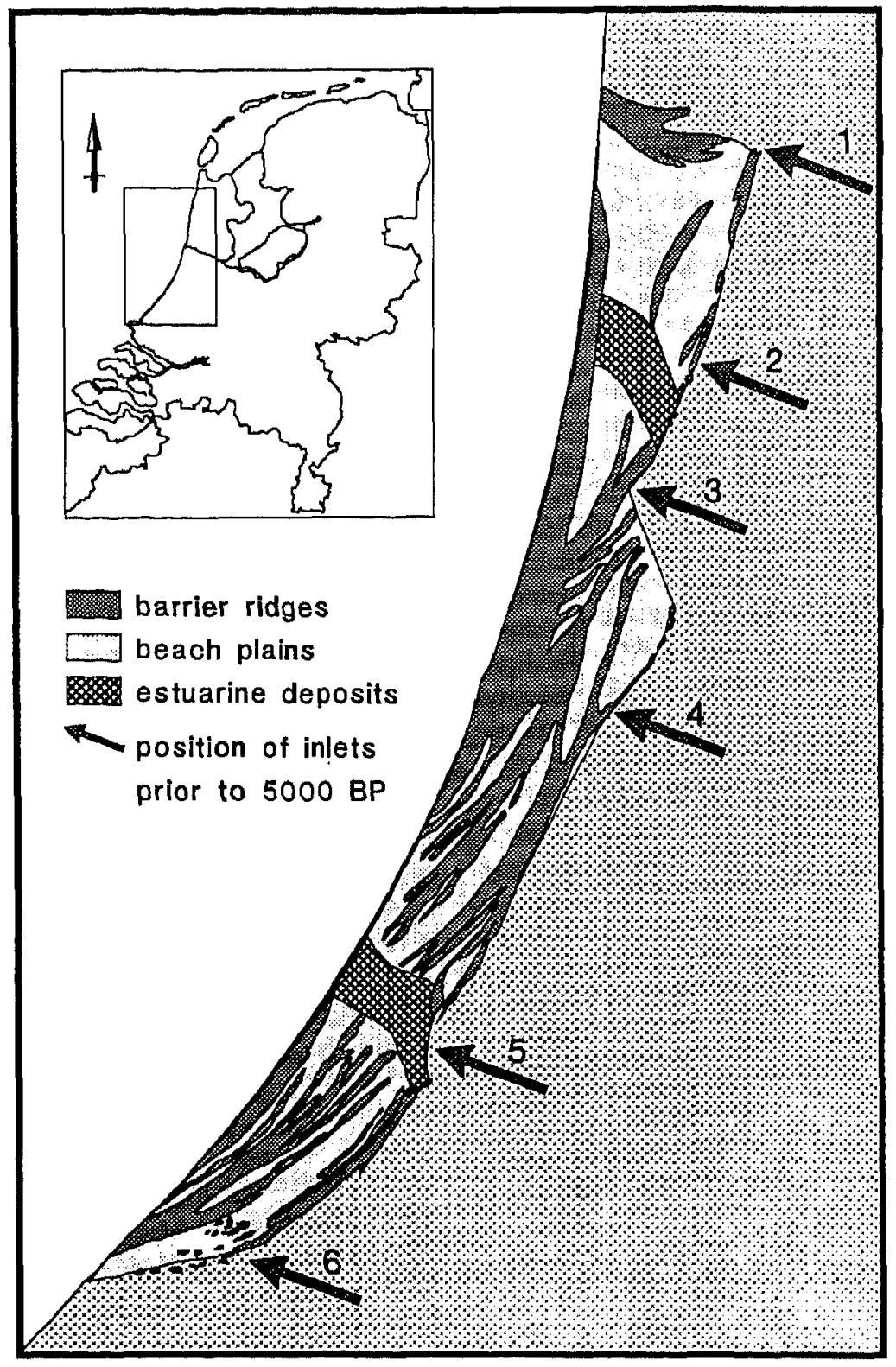

Fig. 10. Beach ridges and beach plains of the barrier complex of Holland. $1=$ Alkmaar-Bergen Inlet; $2=$ Uitgeest Inlet; $3=$ Oer-IJ Inlet; 4=Hoofddorp Inlet; $5=$ Oude Rijn Inlet; $6=$ Rijswijk Inlet. After Jelgersma et al. (1970), De Mulder and Bosch (1982), Westerhoff et al. (1987) and many unpublished data.

Due to the fact that the rivers traversed the same general area up to the Subboreal, this diachronous alluvial plain was a major source of sand by reworking of the channel deposits during shoreface retreat. It became a soft-rock promontory because the removal of sand by longshore drift and tidal currents was insufficient to compensate for the supply by shoreface retreat at the fast rate of postglacial sea-level rise.

\section{Barrier progradation in the Subboreal}

The barrier complex consists of an alternation of ridges and beach plains (Fig.10), which, on the 

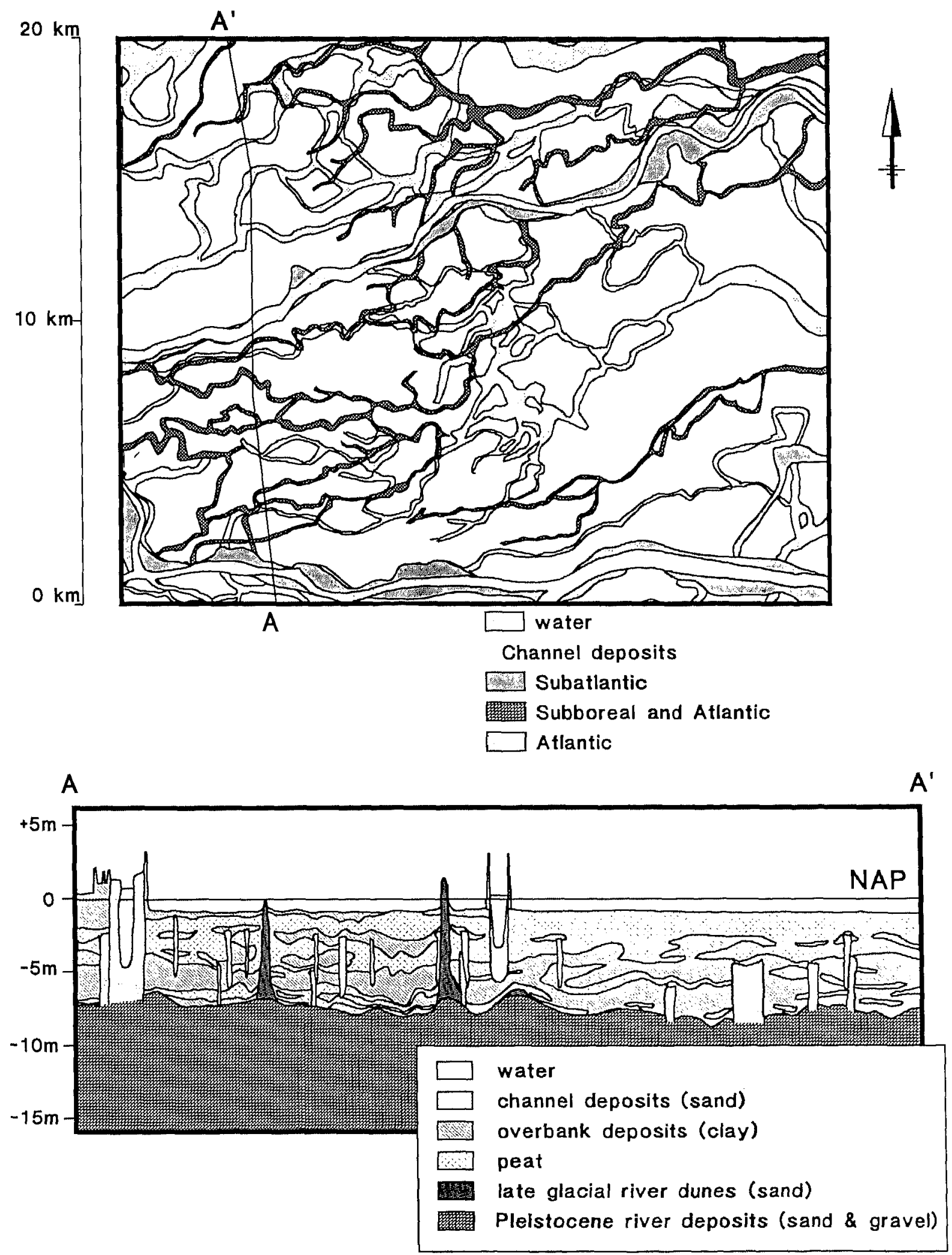

Fig.11. Holocene alluvial plain deposits in the area east of Rotterdam. For location, see inset in Fig.7 (after Van de Meene, 1984). 
western side, is buried beneath a much younger cover of dune sands, the so-called Younger Dunes (Jelgersma et al., 1970). The main difference between ridges and plains is that the former have low dunes, whereas the latter lack aeolian deposits and have a cover of peat often underlain by mudflat and/or estuarine sediments near the inlets. Based on the study of sedimentary sequences of the barrier complex in pits excavated for construction work around Alkmaar, Beets et al. (1981) found that landward dipping, large-scale cross bedding associated with breaker bars were the dominant sedimentary structure in the intertidal reach of the beach plain sequences, whereas horizontal plain beds characterize the intertidal deposits of beach ridge sequences. In addition, ${ }^{14} \mathrm{C}$ dates on articulated shells suggest a difference in progradation rate, with beach plain sequences forming during rapid progradation.

As, at present, the intertidal breaker bars form during fair weather and are destroyed by storms, Beets et al. (1981) state that .... "Beach plain sequences form in periods of rapid progradation when the beach gradient is low and the beach is sheltered from onshore storms by shoals ... Dune ridges, on the other hand, are promoted by a higher beach gradient and no or only little progradation of the beach". They point to the similarity with the cheniers and ridges of the U.S. Gulf of Mexico coast and they state that the alternation of ridges and beach plains in the Dutch barrier complex might be due to changes in sediment supply.

When Beets et al. (1981) studied these sedimentary sequences little was known of the coastal configuration prior to 4000 yrs B.P. and the sand necessary for progradation was thought to have been derived from both overstepped barriers offshore and from the "delta" of the Rhine and Meuse (Van Straaten, 1965). Consequently, changes in the supply of sediment either meant variation in the discharge of the rivers or variations in wave climate. However, now that we know that the ebb-tidal deltas of closing inlets are important sources of sand for progradation of the barrier in the Subboreal, the changes in sediment supply as expressed by the alternation of beach plains and ridges can largely be explained by the succession of inlet disappearance. In this context it should be noted that the cross-shore processes after inlet closure occur relatively quickly and relatively locally, while longshore processes are expected to occur relatively gradually and over greater longshore distances. It is to be expected that the observation of these processes is not straightforward because of the requirement of a high spatial resolution of geological profiles. Keeping in mind that beach plain sequences represent rapid progradation and the supply of large amounts of sand, the maps shown in Fig. 12 show the following history of progradation:

(1) Between 5000 and 4500 yrs B.P. most sand was supplied by sources near Rijswijk and Haarlem. The former was the ebb-tidal delta of the Rijswijk Inlet, which was an important source for the beach plain east of The Hague, and the latter was that of the Hoofddorp Inlet, which provided most of the sand for the triangular beach plain east of Haarlem. Both inlets closed shortly before $5000{ }^{14} \mathrm{C}$ yrs B.P. In addition, longshore transport would have brought sand from the cape west of the Hook of Holland. Longshore transport forced the inlet of the Oer-IJ towards the north. Note that progradation in the The Hague and Haarlem area started at least 500 years before stabilization of the barrier in the Alkmaar area. This was due to the difference in the size of the back-barrier area. In the Late Glacial the Haarlem/The Hague area was the flat divide between the northern valley and the alluvial plain of the Rhine and Meuse (Fig.5). Consequently, the back-barrier area which formed during the late Atlantic was smaller in size and was filled more rapidly than the tidal basin east of Alkmaar. The Rijswijk and Hoofddorp channels had a short life span in comparison with the channels in the north. They closed earlier ( $\simeq 5200$ yrs B.P.) because of rapidly declining tidal prisms.

(2) Between 4500 and 4000 yrs B.P. the sand sources did not fundamentally change, except for the area north of Haarlem. Here, the oldest preserved barrier dates from about 4500 yrs B.P. It closed the Uitgeest Inlet and forced the AlkmaarBergen Inlet to move northward (De Mulder and Bosch, 1982). Until that time the Inlet was a major sink for sand, both from the south and the north. 

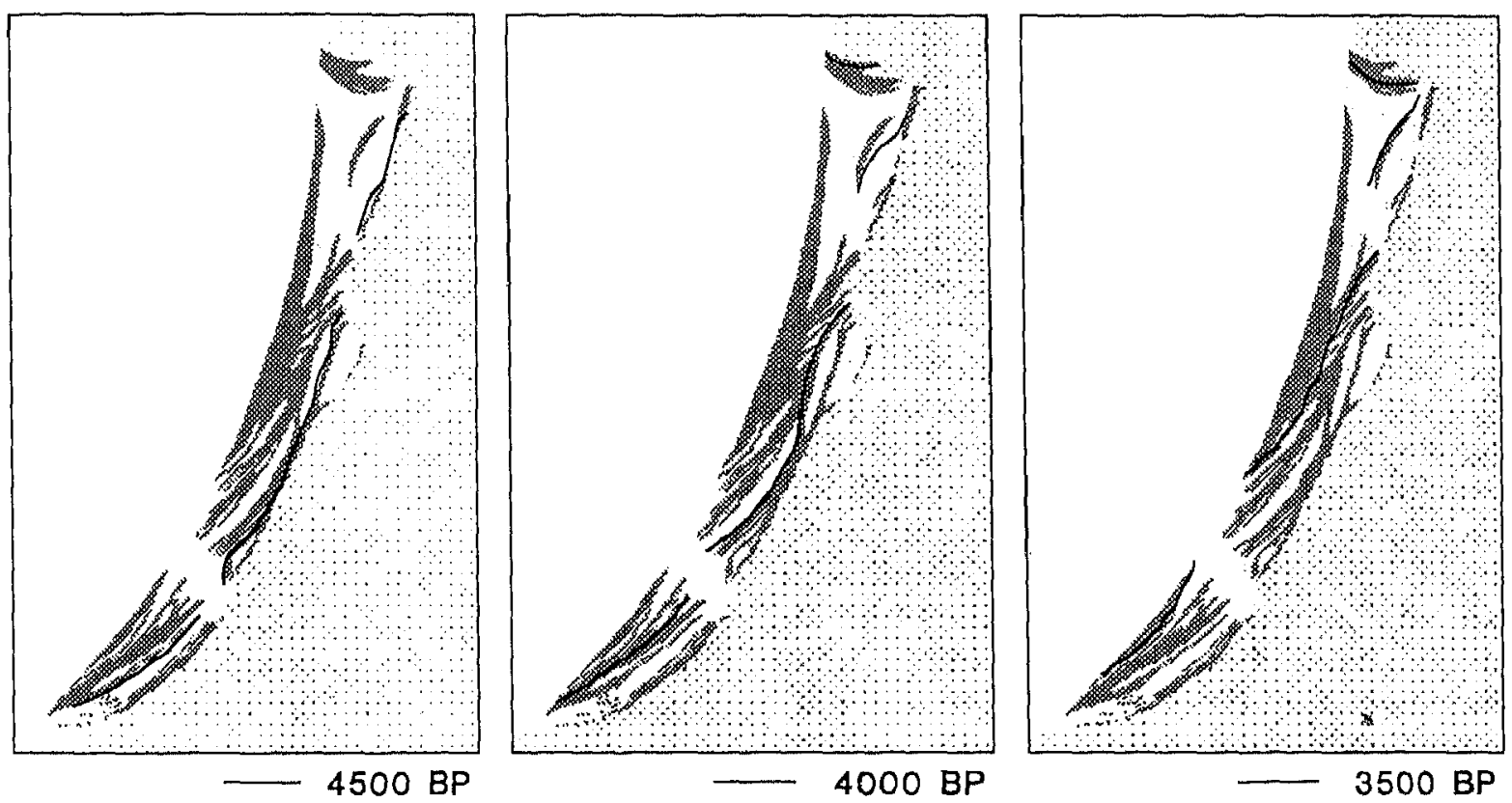

Fig. 12. Isochrons of the prograding barricr sequence of Holland. The isochrons are based on more than $400{ }^{14} \mathrm{C}$ dates of shells in the barrier sequence and peat overlying the beach plains. Only some of these dates have been published (see Westerhoff et al. (1987), De Mulder and Bosch (1982), Roep et al. (1983), Van de Plassche (1982) and Van Staalduinen (1979). The others are from the files of the Geological Survey of The Netherlands.

Nevertheless, the amount of sand provided by the Uitgeest ebb-tidal delta was sufficient to cause progradation of the barrier directly south of the inlet, and the formation of the beach plain south of Alkmaar. The shape of the barriers around Leiden Inlet suggests that this tributary of the Rhine started to bring a modest amount of sand to its mouth from 4500 yrs B.P. onward.

(3) Between 4000 and 3500 yrs B.P. progradation proceeded rapidly over the entire length of the coast. Wide beach plains on both sides of Leiden Inlet show that the supply of sand by this branch of the Rhine increased considerably compared to the preceding period, suggesting that at $4000 \mathrm{yrs}$ B.P. this was the main or probably the only discharge channel of the river. The 3500 yrs B.P. shoreline in this area was situated near the present coastline. The northward drift of the Oer-IJ Inlet continued. At the same time the Alkmaar-Bergen Inlet narrowed.

(4) For the period after 3500 yrs B.P. we have no data concerning the barrier sequence for the area in the south, as the coastline prograded seaward of the present shoreline. In the central part progradation proceeded slowly: the $2000 \mathrm{yrs}$ B.P. shoreline was situated near the present shoreline. Most of the progradation since $3500 \mathrm{yrs}$ B.P. occurred in the north: the wide beach plain west of Alkmaar was predominantly formed by sand of the ebb-tidal delta of the Alkmaar-Bergen Inlet, and to a lesser degree, of that of the Oer-IJ ebbtidal delta after 2000 yrs B.P.

For the barrier complex between Rijswijk and IJmuiden (Fig.10), Zitman (1987) has estimated which part of the progradational sequence could be attributed to gradients in wave-driven longshore transport due to the curvature of the shoreline. The calculations are based on "state-of-the-art" longshore drift formulations with a realistic estimate of the associated bandwidth of accuracy. For the calculations, it was assumed that wind and wave climate between 5000 and 3000 yrs B.P. was similar to those of today, and that the slope of the shoreface to a depth of $-10 \mathrm{~m}$ was $1: 200$ instead of the present 1:100. Although the model cannot cope very well with the relatively complicated morphology of the inlet near Leiden, Zitman shows that longshore transport is in no way suffi- 
cient to explain the progradation. Of the 6 billion $\mathrm{m}^{3}$ sand stored in the barrier complex between Rijswijk and IJmuiden, less than 1 billion $\mathrm{m}^{3}$ could have been contributed by longshore transport according to the calculations of Zitman (1987).

Little is known of the development of the barrier of the Texel High in this period. Zagwijn (1986) assumes an uninterrupted barrier from Bergen in the south up to and including the present island of Terschelling in the northeast. Subboreal mudflat deposits behind this barrier are thought to have been fed by channels from the south (AlkmaarBergen Inlet) and the northeast. These mudflat deposits are overlain by eutrophic and oligotrophic peat. The collapse of the oligotrophic peat body in the area of Texel and Den Helder due to drainage by tidal channels from the west around Roman times (Zagwijn, 1986; Westerhoff and Beets, 1987) indicate the nearness of the coastline. Peat is overlain by sandy flood-tidal delta deposits and washover fans of Medieval age fed by a number of channels cutting the barrier, which was then stitl six or more kilometres west of Den Helder (Schoorl, 1973).

Erosion of the alluvial plain south of the barrier complex continued, probaby at an increased rate since 4000 yrs B.P. as the main discharge channel of the Rhine shifted to Leiden. This shift also caused widening of the estuary and after about 3500 yrs B.P., flooding and erosion of the area behind the barrier (Van Staalduinen, 1979).

\section{Barrier behaviour since Roman times}

With the silting up of the last inlet along the coast of Holland the obvious sources of sand for progradation were exhausted. Moreover, because of the continuous retreat of the Texel High in the north and the alluvial plain in the south and simultaneous progradation along the central part of the coast of Holland, gradients of longshore transport decreased in time. The prograding coast reacted to this decrease in sediment supply by steepening of the upper shoreface. Steepening of the slope of the shoreface since the end of the Subboreal was the logical outcome of the coastal progradation model presented by Van Straaten (1965), which shows low shoreface gradients during progradation in the Subboreal. Although Van Straaten's age control on the reconstruction of the Subboreal shoreface is conjectural, as it involves pollen only, recent work by one of us (Van der Valk) on cross sections of the barrier complex based on undisturbed cores with a large number of ${ }^{14} \mathrm{C}$-dated isochrons confirms the process of steepening of the upper shoreface, but shows that this occurs more gradually and started much earlier than assumed by Van Straaten (1965). Stive et al. (1990) point out that along the central part of the coast of Holland longshore net losses in the active zone (extending from the first dune row to a depth of $\pm 8 \mathrm{~m}$ ) are at present so small that the net shoreface feeding of the active zone by wave asymmetry and density-flow driven upwelling can also compensate for the losses due to vertical profile movements by sea-level rise and windinduced transport. This causes the active zone, including the shoreline, to prograde and the lower and middle shoreface to flatten. As a result, the transition between the active zone and the middle shoreface steepens. The quantitative confirmation of these effects is given by Knoester (1990), where, for example, long-term evolution data (1896-1975) on the $-7 \mathrm{~m}$ and $-10 \mathrm{~m}$ depth contours are presented.

With the inlets closed, the sand of their ebbtidal deltas remoulded into barrier sequences, and the barrier of the Texel High still a promontory, the coast of Holland became a more or less closed system in the Subatlantic. Steepening of the shoreface implies less dissipation of wave energy on the shoreface and increasing pressure on the breaker zone and the beach. In the classical case of the barrier-lagoon couple, this would lead to breaching of the barrier during storm, landward transport of sand by washover fans or flood-tidal deltas, landward shift of the barrier and a return to the original slope of the shoreface. Basically, this is what happened to the barrier of the Texel High (Eisma and Wolff, 1983). However, in the case of the coast of Holland between Scheveningen and Bergen the barrier and dune complex had reached a width of up to $8 \mathrm{~km}$ and, consequently, could no longer be breached. The gradual closing of all tidal inlets enhanced this process, logether with 
the formation of progressively higher dunes along the successive barrier coastlines.

Although the present process of steepening of the shoreface in the case of the coast of Holland leads to shoreline progradation, the maps of the barrier sequence (Figs.10 and 12) show considerable truncation of the isochrons. This erosion is due to removal of sand from the shoreline system by aeolian transport. Until Roman times the dunes were low with an extensive shore-parallel and a narrow shore-normal distribution. Shore-normal wind transport was probably inhibited by the "wet" beach plains, where sufficiently wide, and by rapid stabilization of the dunes by vegetation. For reasons which are still not fully understood, the situation changed between 800 and $1000 \mathrm{AD}$ and large-scale overblowing of the barrier complex started (Jelgersma et al., 1970; Zagwijn, 1984; Van der Valk, 1987; Pool and Van der Valk, 1988). Pool and Van der Valk computed that in various steps between 800 and $1850 \mathrm{AD}$ about 1.5 billion $\mathrm{m}^{3}$ of sand was transported inland between the Hook of Holland and the Hondsbosse Sea. Dyke. Rigorous coastal protection, including the systematic planting of marram grass in the dunes bordering the shoreline, started in the middle of the last century and brought an end to overblowing and associated coastal erosion. Yearly measurements of the dune foot and high and low waterlines were started simultaneously and have recorded a stable to slightly prograding shoreline between Scheveningen and Bergen since then.

Between 1000 and $1200 \mathrm{AD}$ the barrier of the Texel High, which was situated several kilometers west of the present shoreline (Schoorl, 1973; Eisma and Wolff, 1983), was cut by a number of relatively small inlets, formed by breaching of the barrier during storms. Most of these inlets have small tidal basins and thus closed up soon after by silting. Occasionally, they were closed by damming. However, the inlet west of Den Helder enlarged its tidal basin at the expense of the others by erosion of the peat land behind the barrier (Sha, 1990). When this channel made connection with the Wadden Sea and Lake Flevo, the remnant of the former tidal basin of Holland, its importance increased rapidly. On the basis of historical maps, Sha (1990) demonstrates that between 1500-the date of the oldest nautical map-and today the tidal prism of Texel Inlet gradually increased from about 250 to 1100 million $\mathrm{m}^{3}$. Today, Texel Inlet has become the most important inlet of the western Wadden Sea, and it is estimated that the loss of sand through the inlet to the Wadden Sea is 4.5 million $\mathrm{m}^{3} / \mathrm{yr}$ (Stive, 1989). This development implies that retreat of the barrier of the Texel High continues, although the original cause-its protruding nature - has been eliminated.

Distribution of the early Medieval estuarine sediments in the area south of Scheveningen shows that at that time the offshore barrier sequence had been almost completely eroded.

\section{Sinks and sources}

If we take the length of the barrier complex between Scheveningen and Bergen at $75 \mathrm{~km}$, its mean width at $8 \mathrm{~km}$, and the mean base of the sequence at $15 \mathrm{~m}$, it contains about $9 \times 10^{9} \mathrm{~m}^{3}$ of sediment below present sea level. If we correct for some clay in the lower half and, locally, overblown peat on top of beach plain sequences, the total sand content is estimated to be about $8 \times 10^{9} \mathrm{~m}^{3}$. As shown by Pool and Van der Valk (1988) the Younger Dunes covering the barrier complex contain another $1.5 \times 10^{9} \mathrm{~m}^{3}$. A rough estimate of the sand deposited between 5000 and 3000 yrs B.P. in the tidal basin of the Bergen-Alkmaar Inlet is 0.5 $x 10^{9} \mathrm{~m}^{3}$. This implies that 10 billion $\mathrm{m}^{3}$ of sand were deposited in the barrier sequence and associated mudflats of Holland since 5000 yrs B.P.

Demonstrable sources of the sand are the ebbtidal deltas of the closing inlets, the retreating headlands south of Scheveningen and north of Bergen, and the delta of the River Rhine near Leiden.

As shown in Table 2, the collective ebb-tidal deltas in front of the coast of Holland shortly before 5000 yrs B.P. contained about 3.5 billion $\mathrm{m}^{3}$ of sand.

Sand from the Texel High and from the alluvial plain south of Scheveningen would have been transported to the prograding barrier sequence by longshore drift. As mentioned earlier, Zitman (1987) calculated that between 5000 and 3000 yrs B.P. about $0.8 \times 10^{9} \mathrm{~m}^{3}$ of sand was deposited 
from longshore drift in the prograding barrier sequence between Scheveningen and IJmuiden. A very rough extrapolation gives $1.2 \times 10^{9} \mathrm{~m}^{3}$ for the same period over the entire prograding barrier coast (Scheveningen to Bergen), and twice that amount if we extrapolate up to today (note that ${ }^{14} \mathrm{C}$ years are not solar years). In his calculation Zitman (1987) did not take the Texel High into account as this source was separated from the barrier sequence by the Alkmaar-Bergen Inlet. However, after closure of the inlet some sand from the north would also have been incorporated into the barrier sequence from longshore transport, so we estimate that the total amount of sand introduced from the retrcating capes by longshore transport is around $3 \times 10^{9} \mathrm{~m}^{3}$.

From 4500 yrs B.P. onwards the tributary of the Rhine debouching west of the present city of Leiden started to build a modest delta. In time this tributary developed into the main branch with a delta, which in part was situated in the present offshore area but which has been removed by later coastal erosion. By extrapolation a deltaic sand body can be reconstructed which contains about $0.5 \times 10^{9} \mathrm{~m}^{3}$ of sand if we place its base at a depth of $15 \mathrm{~m}$. In conclusion, we can state that if we assume that all sand stored in the ebb-tidal deltas of the closing inlets can be used for barrier progradation, and we assume a Rhine delta depth of $15 \mathrm{~m}, 7$ billion of the 10 billion $\mathrm{m}^{3}$ of sand stored in the Holland barrier complex can be obtained from clear and demonstrable sources. The remaining 3 billion $\mathrm{m}^{3}$ must have come from reworking of Pleistocene sands in the southern North Sea (i.e. the inner shelf and lower shoreface) and from landward transport by shore-normal processes (Eisma, 1968; Wiersma, 1985; Wiersma and Van Alphen, 1988). This does not appear unrealistic because it would imply a net cross-shore sediment transport rate of the same order of magnitude as the 8 to $14 \mathrm{~m}^{3} / \mathrm{m} / \mathrm{yr}$ derived by Roelvink and Stive (1990) for the present net cross-shore transport rate at the $10 \mathrm{~m}$ isobath of the coast of Holland based on a combination of calculations and observations.

\section{Summary and conclusions}

The long-term history of the coast of Holland is basically one of smoothing and straightening of a gently undulating Late Weichselian landscape. The system operated by erosion of the headlands, removal of the sand by longshore transport and deposition in the gap between. In this respect the Holland coast is very similar to other retreating barriers of the world (e.g., Nummedal, 1988; Morton, 1979; Kraft et al., 1987). However, in addition to the longshore drift, there were also very efficient shore-normal processes which brought in sediment from the North Sea. The rough sand budget given above indicates that at least $30 \%$ and, when we include all sand of the ebb-tidal deltas, at most $65 \%$ of the 10 billion $\mathrm{m}^{3}$ of sand stored in the barrier complex was derived from the North Sea. The sands of the mudflat deposits behind this barrier also originated predominantly from the North Sea, so the total amount of sand transported landwards by shore-normal processes would be still greater.

Although transport across the shoreface in most cases is the result of "waves and currents acting in concert" (Wright, 1987), it can safely be stated that in the case of the coast of Holland tidal flow locally dominated cross-shore transport in the late Atlantic, when the shoreline was cut by a large number of inlets, and a major part of the sand later to be used for progradation was stored in the ebb-tidal deltas of these inlets.

With the progressive closure of the tidal inlets from the south to the north, and the simultaneous progradation of the barrier, the conditions along the coast from Scheveningen to Bergen changed significantly. Closure of the inlets ended the E-W directed tidal flow, probably implying a drastic reduction in shoreward transport of sand from the North Sea shelf and shoreface. Progradation changed the barrier into an $8 \mathrm{~km}$ wide complex, which, under the prevailing wind and tidal climate, became a more or less closed and rigid system. These changes resulted in a gradual steepening of the shoreface. Although supply of sand from the shelf decreased, net shoreward transport along the shoreface continued and brought sand into the breaker zone at a rate surpassing its removal by longshore transport, rip currents and aeolian processes. As the barrier was fixed this resulted in steepening and progradation. Steepening leads to reduced dissipation of wave energy and results in 
increasing wave attack on the shoreline. This is probably one of the causes of erosion of the shoreline and of aeolian overblowing since medieval times.

Simultaneously with progradation of the central part of the coast of Holland, the two enclosing headlands retreated by shoreface erosion. Although the original cause of retreat (i.e., the protruding nature of the headlands) has by now been eliminated, shoreface erosion in the north continues because the barrier of the Texel High, unlike the barrier complex south of Bergen, is and was a narrow coastal strip which could easily be breached during storms, so that eventually the connection with the Wadden Sea was established by way of the Texel Inlet, now a major passage for sand.

\section{Acknowledgements}

We are indebted to our colleagues of the Geological Survey of The Netherlands, Delft Hydraulics, the Rijkswaterstaat and other research institutes for cooperating in the Coastal Genesis Programme. The stimulating environment provided by the Dutch working group of Project 274 of the International Geological Correlation Programme is also appreciated. Saskia Jelgersma, Hans Wiersma, Tom Roep, Erno Oele, Roeland Hillen, Wim de Gans and Ad van der Spek are thanked for commenting on early drafts of the manuscript. Adri Pruissers is thanked for his help in collecting and compiling all the data necessary for the reconstruction of the barrier progradation isochrons.

\section{References}

Beets, D.J., Roep, Th.B. and De Jong, J., 1981. Scdimentary sequences of the sub-recent North Sea coast of the western Netherlands near Alkmaar, Spec. Publ. Int. Assoc. Sedimentol., 5: 133-145.

Beets, D.J., Jelgersma, S. and Westerhof, W.E., 1985. Holocene coastal development in the western Netherlands: indications for major changes in tidal range in time. Modern and Ancient Clastic Tidal Deposits (Utrecht), pp.35-37 (Abstr.).

Bruun, P., 1978. Stability of Tidal Inlets. Theory and Engineering. Elsevier, Amsterdam.

Davis, Jr, R.A. and Hayes, M.O., 1984. What is a wavedominated coast? Mar. Geol, 60: 313-329.

De Mulder, E.F.J. and Bosch, J.H.A., 1982. Holocene stratigraphy, radiocarbon datings and paleogeography of central and northern North Holland (The Netherlands). Meded. Rijks Geol. Dienst, 36 (3): 111-160.

De Ronde, J.G., 1982. Changes of relative mean sea-level and of mean tidal amplitude along the Dutch coast. Proc. Nato Workshop (Utrecht), p.18.

Dijkman, M.J., Bakker, W.T. and De Vroeg, J.H., 1990. Prediction of coastline cvolution for the Holland coast. The Dutch Coast. Proc. Int. Conf. Coastal Eng., 22nd, Pap. 7, ASCE, New York.

Edelman, T, and Eggink, D.N., 1962. Some characterstics of the Dutch coast. Proc. Int. Conf. Coastal Eng., 8th, pp.756-764.

Eisma, D., 1968. Composition, origin and distribution of Dutch coastal sands between Hoek van Holland and the Island of Vlieland. Neth. J. Sea Res., 4: 123-267.

Eisma, D. and Wolff, W.J., 1983. The development of the westernmost part of the Wadden Sea in historical time. In; K.S. Dijkema, H.E. Reineck and W.J. Wolff (Editors), Geomorphology of the Wadden Sea Area. Balkema, Rotterdam, pp.95-103.

Eysink, W.D., 1990. Morphologic response of tidal basins to changes. The Dutch Coast. Proc, Int. Conf. Coastal Eng, 22nd, Pap. 8, ASCE, New York.

Franken, A.F., 1987. Rekonstruktie van het paleo-getijklimaat in de Noordzee. Delft Hydraul. Lab., X 0029-00, 74 pp.

Haans, J.C.F.M., 1954. De Bodemgesteldheid van de Haarlemmermeer. Versl. Landbouwk. Onderz., 60 (7): 154 pp.

Hageman, B.P., 1969. Development of the western part of The Netherlands during the Holocene. Geol. Mijnbouw, 48: 373-388.

Jelgersma, S., 1961. Holocene sea-level changes in The Netherlands. Meded. Geol. Sticht., C, VI (7): $100 \mathrm{pp.}$

Jelgersma, S., De Jong, J., Zagwijn, H.W. and Van Regteren Altena, J.F., 1970. The coastal dunes of the western Nctherlands: geology, vegetational history and archcology. Meded. Rijks Geol. Dienst, Nieuwe Ser., 21: 93-167.

Knocster, D., 1990. Morphology of the Holland coast. Rijkswaterstaat, Dienst Getijdewateren, Rep. GWAO-90.010 (in Dutch).

Kohsiek, L.H.M., 1988. Reworking of former ebb-tidal deltas into large longshore bars following the artificial closure of the tidal inlets in the Southwest Netherlands. In: P.L. de Boer, A. van Gelder and S.D. Nio (Editors). Tide-Influenced Sedimentary Environments and Facies. Reidel, Dordrecht, pp. 113-122.

Kollen, J., 1987. Overzicht van input gegevens. Kustgenese, Deeirapport I. Rijkswaterstaat, Dienst Getijdewateren, $49 \mathrm{pp}$.

Kraft, J.C., Chrzastowski, M.J., Belknap, D.F., Toscano, M.A. and Fletcher, C.H., 1987. The transgressive barrier-lagoon coast of Delaware: morphostratigraphy, sedimentary sequenes and responses to relative rise in sea-level. In: $D$. Nummedal et al. (Editors), Sea-Level Fluctuation and Coastal Evolution. SEPM Spec. Publ., 41: 129-143.

Morton, R.A., 1979. Temporal and spatial variations in shoreline changes and their implications, examples from the Texas Gulf Coast. J. Sediment. Petrol., 49: 1101-1111.

Nummedal, D., 1988. Barrier Islands, CRC Handbook of Coastal Processes and Erosion. pp.77-121. 
O'Brien, M.P., 1969, Equilibrium flow areas in inlets on sandy coasts. J. ASCE, Waterways Harbour Div., 95: 43-51.

Pons, L.J., Jelgersma, S., Wiggers, A.J. and De Jong, J.D., 1963. Evolution of The Netherlands coastal area during the Holocene. Verh. Kon. Geol. Mijnbouwk. Genoots., 2l(2): 197-208.

Pons, L.J. and Wiggers, A.J., 1959-1960. De holocene wordingsgeschiedenis van Noord-Holland en het Zuiderzeegebied. Tijdschr. Kon. Ned. Aardrijksk. Genoots., 76: 104-152 and 77: 1-57.

Pool, M.A. and Van der Valk, L., 1988. Volumeberekening van het Hollandse en Zeeuwse Jonge Duinzand. Rijks Geol. Dienst, BP 10705, Rep. 882657.

Pruissers, A.P. and De Gans, W., 1988. De bodem van Leidschendam. Jaarboek Gemeente Leidschendam 1988. pp.11-17.

Reineck, H.E. and Singh, J.B., 1973. Depositional Sedimentary Environments. Springer, $439 \mathrm{pp}$.

Roelvink, J.A. and Stive, M.J.F., 1990. Sand transport on the shoreface of the Holland coast. The Dutch Coast. Proc. Int. Conf. Coastal Eng., 22nd, Pap. 5, ASCE, New York.

Roep, Th.B., 1984. Progradation, erosion and changing coastal gradient in the coastal barrier deposits of the western Netherlands. Geol. Mijnbouw, 63: 249-258.

Roep, Th.B. and Beets, D.J., 1988. Sea-level rise and paleotidal levels from sedimentary structures in the coastal barriers in the western Netherlands since $5600 \mathrm{BP}$. Geol. Mijnbouw, 67: 53-60.

Roep, Th.B., Van de Plassche, O., Van der Valk, L. and Ruegg, G.H.J., 1983. Sedimentologie van de strandwalafzettingen onder 's-Gravenhage en Rijswijk. Meded. Rijks Geol, Dienst, 37(1): 63-95.

Schoorl, H., 1973. Zeshonder Jaar Water en Land. WoltersNoordhof, Groningen, $534 \mathrm{pp}$

Sha, L.P., 1989. Cyclic morphological changes of the ebb-tidal delta, Texel Inlet, The Netherlands. Geol. Mijnbouw, 68: 3548.

Sha, L.P., 1990. Sedimentological studies of the ebb-tidal deltas along the West Frisian Islands, The Netherlands. Ph.D. Thesis (Geol. Ultraiectina, 64: $159 \mathrm{pp}$.).

Stive, M.J.F., 1986. Cross-shore sediment transport. Proc. Int. Conf. Coastal Eng., 20th, ASCE, New York.

Stive, M.J.F., 1987. Hoofdrapport Kustgenese: Grootschalige vorming en ontwikkeling van de Nederlandse kust. Rijkswaterstaat, Dienst Getijdewateren, Den Haag, 83 pp.

Stive, M.J.F., 1989. Kustvoorspelling: voorspelling ontwikkeling kustlijn 1990-2090. Rijkswaterstaat, Dienst Getijdewatern, Tech. Rapp. 5, H825, 66 pp.

Stive, M.J.F., Roelvink, J.A. and De Vriend, H.J., 1990. Largescale coastal evolution concept. The Dutch Coast. Proc. Int. Conf. Coastal Eng., 22nd, Pap. No. 9, ASCE, New York.

Stolk, A., 1989. Zandsysteem kust. Rijkswaterstaat, Dienst Getijdewateren, Tech. Rapp. 1, 97 pp.

Ter Wee, M.W., 1983. The Saalian glaciation in the northern Netherlands. In: J. Ehlers (Editor), Glacial Deposits in North-West Europe. Balkema, Rotterdam, pp.405-413.

Van Alphen, J.S.L.J. and Damoiseaux, M.A., 1989. A geomorphological map of the Dutch shoreface and adjacent part of the continental shelf. Geol. Mijnbouw, 68: 433-445.
Van de Meene, E.A., 1984. Beschrijving van kaarten en profielen. Rijks Geol. Dienst, OP 6006.

Van den Berg, J.H., 1977. Morphodynamic development and preservation of physical sedimentary structures in two prograding recent ridge and runnel beaches along the Dutch coust. Geol. Mijnbouw, 56: 185-202.

Van den Berg, J.H., 1986. Aspects of sediment- and morphodynamics of subtidal deposits of the Oosterschelde (The Netherlands). Rijkswaterstaat Commun. 43, $126 \mathrm{pp}$.

Van de Plassche, O, 1982. Sca-level change and water-level movements in The Netherlands during the Holocene. Meded. Rijks Geol. Dienst, 36(1): 93 pp.

Van de Plassche, O. and Roep, Th.B., 1989. Sea-level changes in The Netherlands during the last 6500 years: basal peat vs. coastal barrier data. In: D.B. Scott et al. (Editors), Late Quaternary Sea-Level Correlation and Applications. Kluwer, pp.41-56.

Van der Valk, L., 1987. Duinvorming en kustontwikkeling: een relatie? In: M. Jansen and L. van der Valk (Editors), Duinen bij Den Haag: de Moeite Waard! Suppl. Duin 1987, 1/2, pp.18-20.

Van der Valk, L., Westerhoff, W.E. and De Jong, J., 1985. Mid-Holocene wave-dominated clastic tidal deposits at Rijswijk in the western part of The Netherlands. Symp. Modern and Ancient Clastic Tidal Deposits (Utrecht), pp.145-149 (Abstr.).

Van Malde, J., 1984. Voorlopige uitkomsten van voortgezet onderzoek naar de gemiddelde zeeniveau's in de Nederlandse kustwateren. Rijkswaterstaat, Dir. Waterhuishouding Waterbeweging, Nota WW-WH 84.04, 26 pp.

Van Staalduinen, C.J., 1979. Toelichtingen bij de Geologische Kaart van Nederland, 1: 50.000 . Blad Rotterdam West (37W). Rijks Geol. Dienst, Haarlem, 140 pp.

Van Straten, L.M.J.U., 1961. Directional effects of winds, waves and currents along the Dutch North Sea coast. Geol. Mijnbouw, 40: 333-346 and 363-391.

Van Straaten, L.M.J.U., 1965. Coastal barrier deposits in South and North Holland-in particular in the area around Scheveningen and IJmuiden. Meded. Geol. Sticht. Nieuwe Ser., 17: 41-75.

Van Vessem, P., 1989. Indeling Hollandse kust in erosie en sedimentatiegebieden. Notitie Rijkswaterstaat Dienst Getijdewateren.

Westerhoff, W.E. and Beets, D.J., 1987. Sturmdeltas und junge Duenen. Zusammenhaengende Bildungen der post-Roemische Kuestenentwicklung in Nord-Holland, Kurzfassungen der Vortraege 54-Tagung der Arbeitsgemeinschaft NW-Deutscher Geologen, Norderney. pp.15-17.

Westerhof, W.E., De Mulder, E.F.J. and De Gans, W., 1987. Toelichtingen bij de Geologische Kaart van Nederland, 1: 50.000. Blad Alkmaar West en Alkmaar Oost (19W en 190). Rijks Geol. Dienst, Haarlem, 227 pp.

Wiersma, J., 1985. De kust in vier dimensies. Colloq. Delft Hydraul., Kustontwikkeling: Verleden, Heden en Toekomst, pp.4.1 -4.10.

Wiersma, J. and Van Alphen, J.S.L.J., 1988. The morphology of the Dutch shoreface between Hook of Holland and Den Helder. In: P.L. de Boer, A. van Gelder and S.D. Nio (Editors), Tide-Influenced Sedimentary Environments and Facies. Reidel, Dordrecht, pp.101-111. 
Wright, L.D., 1987. Shelf-surfzone coupling: diabathic shoreface transport. In: N.C. Kraus (Editor), Coastal Sediments 87. ASCE, Vol. I, pp.25-40.

Zagwijn, W.H., 1984. The formation of the Younger Dunes on the west coast of The Netherlands (AD1000-1600). Geol Mijnbouw, 63: 259-269.
Zagwijn, W.H., 1986. Nederland in het Holoceen. Rijks Geol. Dienst, Haarlem, 46 pp.

Zitman, T.J., 1987. Analyse van de rol van langstransport bij de ontwikkeling van de Hollandse kust. Deelrapport $\mathrm{V}$, Kustgenese, Rijkswaterstaat, Dicnst Getijdewateren, The Hague, 66 pp. 